\title{
Analysis and Design Consideration of a High Sensitivity Silicon Avalanche Photodiode Receiver for Low Frequency Applications
}

\author{
Bojan Gergič, Denis Đonlagić
}

University of Maribor, Faculty of Electrical Engineering and Computer Science, Maribor, Slovenia

\begin{abstract}
Silicon avalanche photodiodes (APDs) are designed predominantly for high-speed communication applications, but they can also offer interesting low-light application solutions in lower frequency bands. The design and analysis of a high sensitive silicon avalanche photodiode (APD) receiver for low-light fiber-optical sensor applications is described in this paper. The presented analysis shows relatively significant differences in the overall achievable signal-to-noise and distortion ratio (SINAD) of an optical receiver when using otherwise apparently very similar APDs. Furthermore, to maximize SINAD for the selected APD at a given target total receiver gain, an optimum setting exists between diodes' internal gain (reverse voltage) and transimpedance gain. Unfortunately, these optimum settings are usually not determinable from the typical specification parameters that are given by APD suppliers, but rather need to be determined experimentally. A circuit with low-noise transimpedance amplifier (TIA) followed by post-amplifier and low-pass filter has, thus, been designed for measurement of the fiber-optical sensor signals with optical power less than $100 \mathrm{pW}$ at 20 $\mathrm{kHz}$ bandwidth. The overall SINAD of a receiver circuit is highly dependent on APD excess noise and, therefore, several receiver circuits with different APDs have been built and tested. The receiver responsivity 5.5 GV/W and SINAD of more than $20 \mathrm{~dB}$ are achieved with the optimally selected APD.
\end{abstract}

Keywords: Optoelectronics; optical receivers; avalanche photodiode (APD); fiber-optical sensors

\section{Načrtovanje in analiza visoko občutljivega optičnega sprejemnika s silicijevo plazovno fotodiodo za nizkofrekvenčne aplikacije}

\begin{abstract}
Izvleček: Silicijeve polprevodniške plazovne fotodiode so pretežno načrtovane za visoke hitrosti v komunikacijah, vendar lahko nudijo tudi pri nižjih frekvencah zanimive aplikacijske rešitve s šibko svetlobo. V tem članku je opisano načrtovanje in analiza visoko občutljivega optičnega sprejemnika s silicijevo plazovno fotodiodo za optične vlakenske senzorske aplikacije s šibkimi optičnimi signali. Predstavljena analiza prikazuje relativno velike razlike $v$ doseženem skupnem razmerju med signalom in šumom ter popačenjem (SINAD) optičnega sprejemnika pri uporabi sicer navidezno zelo podobnih plazovnih fotodiod. Poleg tega obstaja za doseganje maksimalnega razmerja SINAD pri izbrani diodi in danem ciljnem skupnem ojačenju optičnega sprejemnika optimalna nastavitev med notranjim ojačenjem (zaporno napetostjo) plazovne fotodiode in ojačenjem transimpedančnega ojačevalnika. Žal teh optimalnih nastavitev običajno ne moremo določiti iz tipičnih parametrov, ki jih podajajo proizvajalci plazovnih fotodiod, ampak jih je potrebno določiti eksperimentalno. Zatorej je bilo načrtano vezje z nizkošumnim transimpedančnim ojačevalnikom in dodatnim ojačevalnikom ter nizkoprepustnim filtrom za merjenje šibkih signalov iz optičnih vlakenskih senzorjev z optično močjo manjšo kot 100 pW pri 20 kHz pasovni širini. Skupno razmerje SINAD sprejemnika je precej odvisno od presežnega šuma plazovne fotodiode, zato je bilo sestavljenih in testiranih več sprejemniških vezij z različnimi plazovnimi fotodiodami. Z optimalno izbiro plazovne fotodiode je bila dosežena odzivnost sprejemnika 5.5 GV/W in razmerje SINAD več kot $20 \mathrm{~dB}$.
\end{abstract}

Ključne besede: Optoelektronika; optični sprejemniki; plazovne fotodiode; optični vlakenski senzorji

*Corresponding Author's e-mail: bojan.gergic@um.si 


\section{Introduction}

A silicon avalanche photodiode (APD) is often used for low-light detection in the visible and near-infrared regions, due to its bias dependent internal gain and its ability to amplify the photogenerated signal by avalanche multiplication [1-4]. Internal current gain is provided in an APD because the photogenerated charge carriers are accelerated in the electrical field and produce further electron-hole pairs through impact ionization. This internal gain mechanism can improve the signal-to-noise ratio (SNR) of an optical receiver which uses an APD instead of a PIN diode [5]. However, the increased sensitivity is limited by the level of excess noise generated by the avalanche process [6]. This additional noise increases with the multiplication, and the optimum internal gain is achieved when the APD noise is approximately equal to the noise of the receiver circuit. The excess noise generated by the avalanche process also varies between different APDs and affects the noise performance of a receiver circuit significantly.

In this paper we present the design of a highly sensitive silicon avalanche photodiode (APD) receiver for low-light fiber-optical sensor applications. The receiver testing procedure, based on SINAD measure, is described and used for optimization between APD multiplication and amplifier gain. The receivers with several different APDs were compared and evaluated after the gain optimization procedure.

\section{Receiver Circuit}

The electrical schematic of the receiver circuit is shown in Figure 1. The optical signal is sensed with the APD connected to the input of the optical receiver in reverse-biasing. The transimpedance amplifier (TIA), which is based on a dual low-noise CMOS operational amplifier LTC6241, was used to convert the diode photocurrent into a voltage. The transimpedance gain equal to $10^{7} \mathrm{~V} / \mathrm{A}$ was set with a thin-film $10 \mathrm{M} \Omega$ feedback resistor R10. A feedback capacitor $\mathrm{C} 14$ provides compensation for the effects of the input capacitance, and stabilizes the circuit [5, 7-9]. The voltage signal from the TIA is then amplified with an AC-coupled post-amplifier, which removes the DC signal component and provides output voltage level adjustment. The gain of the post-amplifier depends on the selected APD, and is in a range between $37 \mathrm{~V} / \mathrm{V}$ and $109 \mathrm{~V} / \mathrm{V}$. The output signal from the post-amplifier is filtered with a linear phase 10th order low-pass filter LTC1569-6 to remove high-frequency noise. The cutoff frequency of the filter is set with a single resistor R15 to $23.7 \mathrm{kHz}$. The receiver power supply voltage is regulated with a $5 \mathrm{~V}$ linear regulator $A D M 7150$, which provides high power supply rejection ( $>90 \mathrm{~dB}$ from $1 \mathrm{kHz}$ to $1 \mathrm{MHz}$ ) and ultralow output noise $(<1.7 \mathrm{nV} / \sqrt{ } \mathrm{Hz})$.

The internal current gain of the APD depends on the applied reverse bias voltage. Typically, reverse bias voltage for silicon APDs is between $80 \mathrm{~V}$ and $200 \mathrm{~V}$. Since the APD gain also varies with the temperature, it is necessary to control the bias voltage to keep a sta-
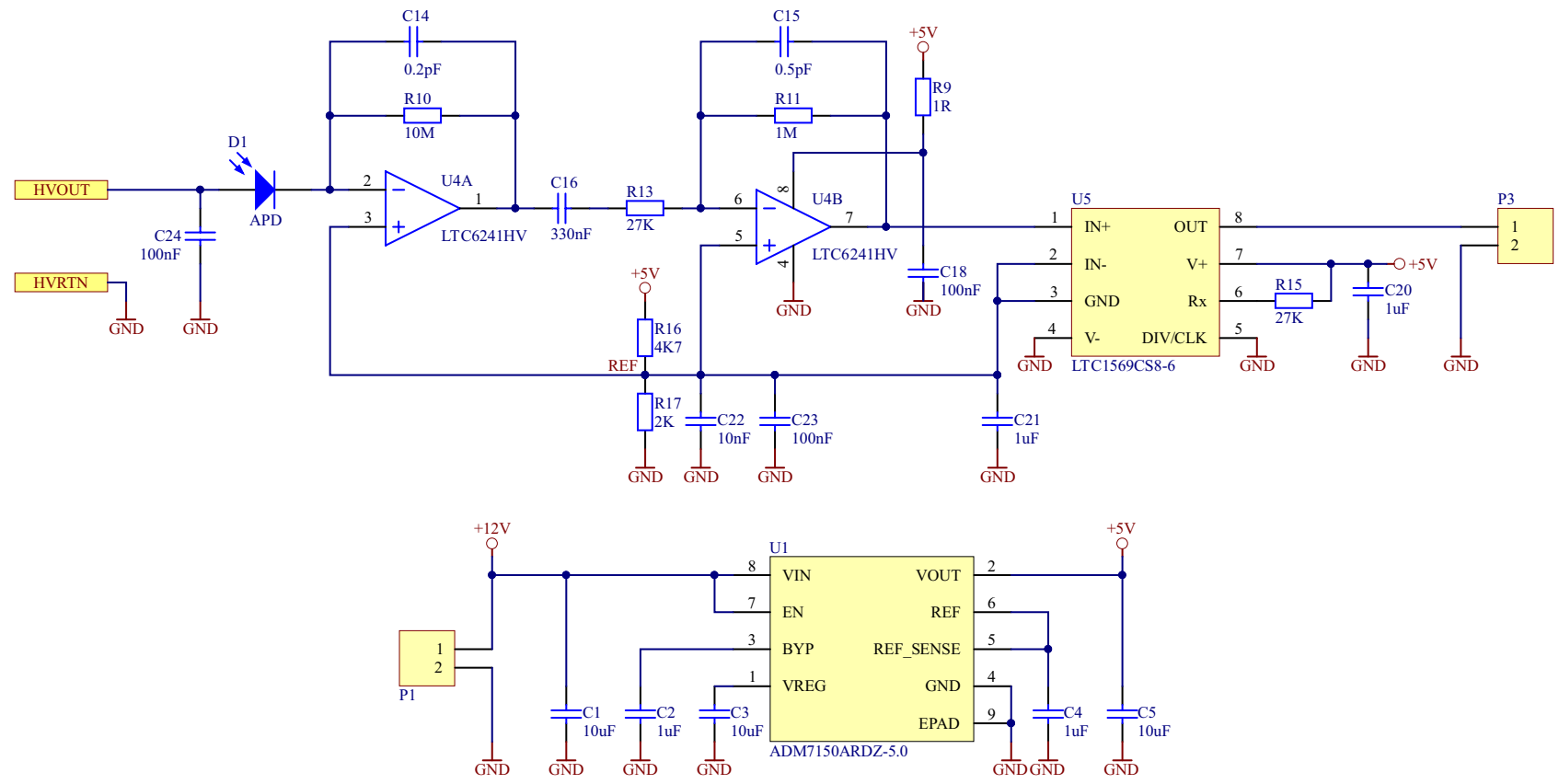

Figure 1: Electrical schematic of the receiver circuit (top) and power supply circuit (bottom). 


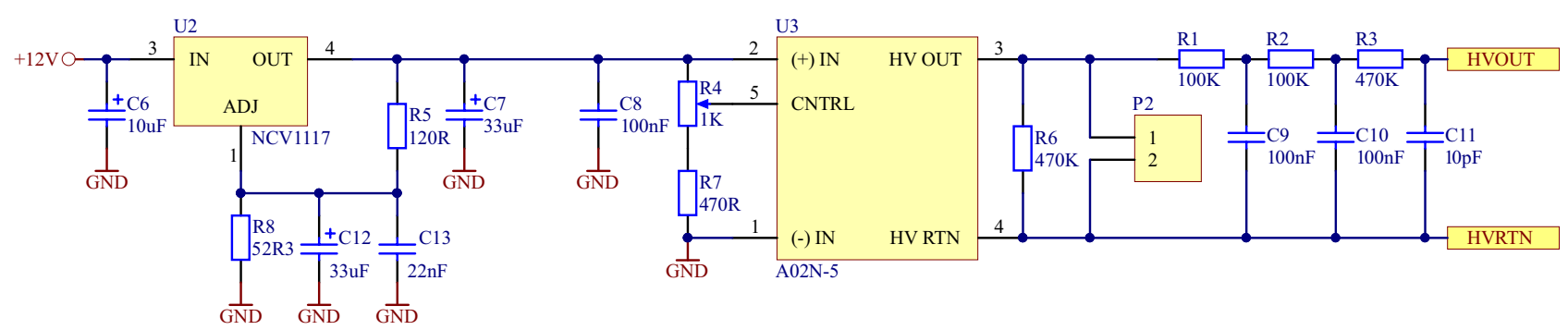

Figure 2: Reverse bias voltage circuit.

ble gain [10]. The reverse bias voltage circuit is shown in Figure 2. The reverse bias high voltage (HV) is provided with an isolated $1 \mathrm{~W}$ miniature proportional DC to HV DC converter module A02N-5 from XP Power. The module converts $5 \mathrm{~V}$ voltage from voltage regulator U2 into high output voltage with a value up to $200 \mathrm{~V}$. The output voltage is set with control voltage applied to a high impedance control pin (CNTRL). This control pin could also be used in closed loop temperature control for APD gain stabilization. The module is loaded with resistor $\mathrm{R} 6$ and low-pass $\mathrm{RC}$ filer, which also reduces output ripple and limits the current through the APD.

Receiver circuits with six different silicon APDs were assembled for testing. The low-pass filter and the converter module $\mathrm{A} 02 \mathrm{~N}-5$ for reverse bias voltage are not fitted on printed circuit boards (PCB) because they are not necessary during the diode comparison test. The reverse bias voltage is obtained from two in series connected high-voltage linear regulated laboratory power supplies PLH120-P from Aim-TTi. Typical APDs, which are commercially available on the market, were selected for this comparison. The characteristics of the tested APDs are shown in Table 1. They provide high multiplication gain and high responsivity in the wave- length range $800 \mathrm{~nm}$ to $950 \mathrm{~nm}$. The APD3 is designed for operation at gains in the range 10 to 20, and can be operated at a fixed bias voltage without the need for temperature compensation. APD5 and APD6 were fiber coupled at manufacture, while the rest have been put into an FC diode housing and filled with black epoxy resin.

\section{Results and discussion}

The measurement system setup shown in Figure 3 was created for the testing of the presented receiver circuit. The fiber-optical sensor signal is simulated with a $50 / 125 \mu \mathrm{m}$ multimode fiber (MM) illuminated with an $850 \mathrm{~nm}$ wavelength infrared emitter (IR LED) driven by a function generator. Forward current through the LED is reduced intentionally with an oversized $10 \mathrm{k} \Omega$ serial resistor, in order to reduce the radiant intensity of the LED and, consequently, optical power from the multimode fiber (MM). The output of the function generator is set to sinewave voltage with DC voltage offset. The optical power from the multimode fiber (MM) was measured with an Agilent 8153A lightwave multim-

Table 1: Electro-optical characteristics of tested APDs.

\begin{tabular}{|c|c|c|c|c|c|c|c|}
\hline Parameter & Unit & APD1 & APD2 & APD3 & APD4 & APD5 & APD6 \\
\hline Wavelength range & $\mathrm{nm}$ & $550-1050$ & $400-1100$ & $600-1050$ & $400-1100$ & $400-1100$ & $400-1100$ \\
\hline $\begin{array}{l}\text { Active area } \\
\text { diameter }\end{array}$ & $\mu \mathrm{m}$ & 500 & 500 & 500 & 230 & 230 & 230 \\
\hline $\begin{array}{c}\text { Responsivity } \\
(850 \mathrm{~nm}, \mathrm{M}=100) \\
\end{array}$ & $\mathrm{A} / \mathrm{W}$ & 50 & 62 & $7.6(\mathrm{M}=15)$ & 50 & 60 & 59 \\
\hline $\begin{array}{l}\text { Breakdown } \\
\text { voltage }\end{array}$ & $\mathrm{V}$ & $150-300$ & $150-400$ & 350 & $120-160$ & $160-240$ & $120-160$ \\
\hline Capacitance & $\mathrm{pF}$ & 2 & 1.5 & 1 & 1.5 & 1 & 0.6 \\
\hline Dark current & $\mathrm{nA}$ & 1 & 1.5 & 20 & 0.05 & 0.5 & 0.05 \\
\hline Noise current & $\mathrm{pA} / \sqrt{ } \mathrm{Hz}$ & 0.2 & 0.4 & 0.1 & - & - & - \\
\hline Manufacturer & & $\begin{array}{l}\text { Laser Com- } \\
\text { ponents }\end{array}$ & $\begin{array}{l}\text { Laser Com- } \\
\text { ponents }\end{array}$ & Excelitas & $\begin{array}{l}\text { Marktech Op- } \\
\text { toelectronics } \\
\end{array}$ & $\begin{array}{l}\text { Shengshi } \\
\text { Optical* }\end{array}$ & $\begin{array}{l}\text { Shenzhen } \\
\text { Yigudian }\end{array}$ \\
\hline Part number & & SAE500NX & SAR500X & $\mathrm{C} 30724 \mathrm{PH}$ & MTAPD-06-003 & $\begin{array}{c}\text { SAP- } \\
\text { 5001M510 }\end{array}$ & GSAPD9-230 \\
\hline
\end{tabular}


eter equipped with an optical head interface module HP 81533B and optical head HP 81520A. The analog output of the optical head interface module was connected to a digital oscilloscope for measurement of the instantaneous optical power signal. The sinewave peak-to-peak value and DC offset on the function generator were changed until the same signal was obtained on the oscilloscope as from the real fiber-optical sensor. The average optical power measured with the Agilent 8153A lightwave multimeter was 320 pW, and the peak-to-peak sinewave instant power measured on the analog output was $90 \mathrm{pW}$. The sinewave frequency was set to $100 \mathrm{~Hz}$ during the instant power measurement, because the bandwidth limitation of the power meter's analog output.

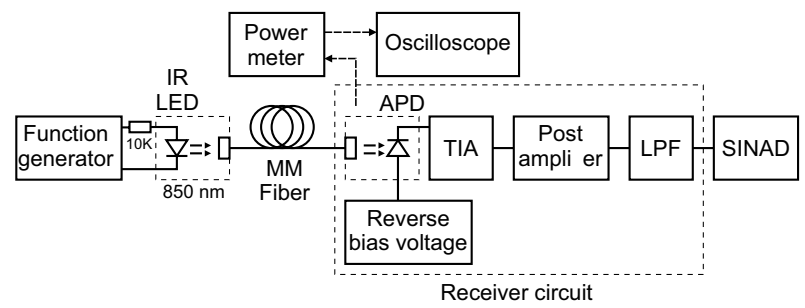

Figure 3: Block diagram of the receiver circuit test system.

The LabVIEW based spectrum analyzer with signal-tonoise and distortion ratio (SINAD) measurement was designed for the noise evaluation. The receiver output signal was digitized with the National Instruments (NI) multifunction DAQ card NI PCl-6251, which has a 16bit analog to digital converter. The sample rate was set to $1 \mathrm{MS} / \mathrm{s}$, and one million samples were acquired to achieve $1 \mathrm{~Hz}$ frequency resolution within a spectral band from DC to $500 \mathrm{kHz}$. The Spectral Measurements and Distortion Measurements (SINAD) Express VIs were used for signal analysis.

The receiver circuit bandwidth is determined with feedback resistance and capacitance, the junction capacitance of the APD and the operational amplifier gain bandwidth product [9]. The transimpedance gain for each tested receiver circuit was increased with the TIA feedback resistor until the bandwidth of $50 \mathrm{kHz}$ was obtained. The maximum useful gain in APDs is limited by the excess noise generated by the stochastic nature of the avalanche multiplication process. This noise degrades the overall SINAD of the receiver circuit at high gain values, and, therefore, the reverse bias voltage was increased until the optimum multiplication gain had been achieved. After the optimum multiplication gain for a particular APD had been found, the gain of the post-amplifier was fine-tuned until reaching a 250 $\mathrm{mV}$ output amplitude. Figure 4 shows spectral measurement results for the receiver circuit with APD1. The top graph shows the spectrum obtained with optimal $140 \mathrm{~V}$ reverse bias voltage applied to the APD, but without an optical signal. This spectrum displays the uniform noise contributed mainly by the TIA circuit, and depends on the TIA gain determined with feedback resistance. The middle graph shows the spectrum after applying the simulated fiber-optical sensor signal with $10 \mathrm{kHz}$ sinewave frequency, as described at beginning of the session. For the clarity of the noise floor the magnitude scale of the graph is limited and therefore the fundamental spectral component of the signal and its second harmonic are cut-off at $1.5 \mathrm{mV}$. The second harmonic is due to nonlinearity of the source and has negligible influence on the results. In addition to uniform noise, the APD noise contribution was evident, and the SINAD obtained with this multiplication gain was 14.9 $\mathrm{dB}$. The further increase of multiplication gain worsened the SINAD, because the excess noise increased faster than the receiver output sinewave amplitude. This is shown in the bottom graph, where the reverse bias voltage is $175 \mathrm{~V}$, the receiver output sinewave amplitude is $0.9 \mathrm{~V}$, but the SINAD drops to $12.8 \mathrm{~dB}$.
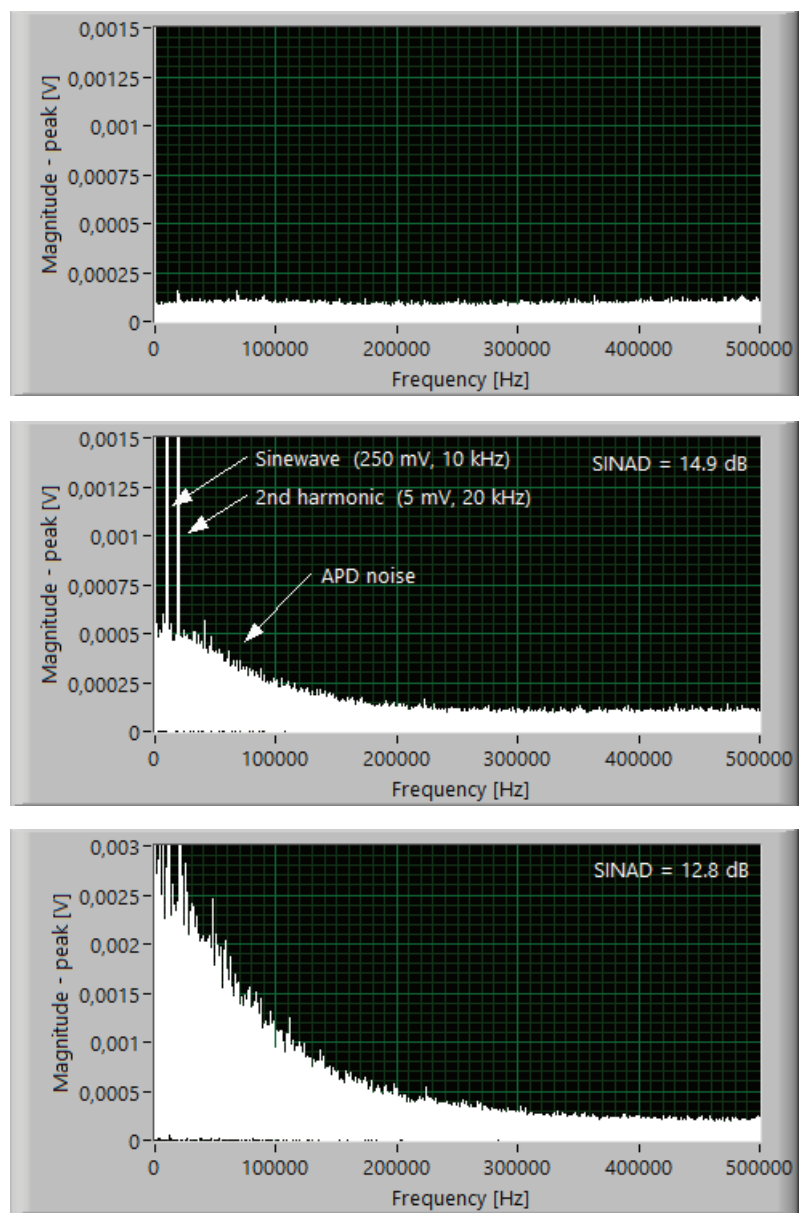

Figure 4: Spectral measurement results for the receiver circuit with APD1. Top - without optical signal, middle with optimal gain, bottom - with high gain. 
The same optimization procedure was applied to all six receiver circuits, and the comparison results are shown in Figure 5. The SINAD rise with the reverse bias voltage to some maximum value, and then began to fall, because the avalanche noise then started to increase faster than the signal. Although the tested APDs have similar electro-optical characteristics, the achieved maximum SINAD depends highly on the APD used. Also, the narrow characteristic with fast SINAD increase and decline around the maximum is inconvenient, since it requires precise reverse bias voltage control. The flattest characteristic was obtained with APD3, which is designed for operation at lower gains, but the obtained maximum SINAD was $3.5 \mathrm{~dB}$ lower than the best achieved result. This is because the lower multiplication gain must be compensated with higher post-amplifier's gain. The best result was obtained with APD1, which has moderate flat characteristic and the highest SINAD of $14.9 \mathrm{~dB}$.

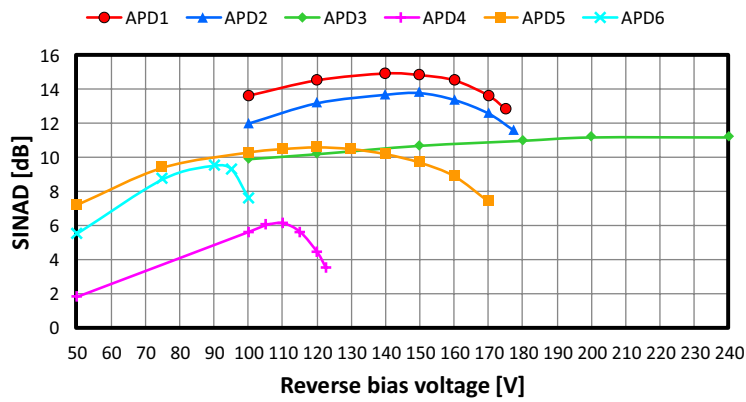

Figure 5: Comparison results for receiver circuits with different APDs.
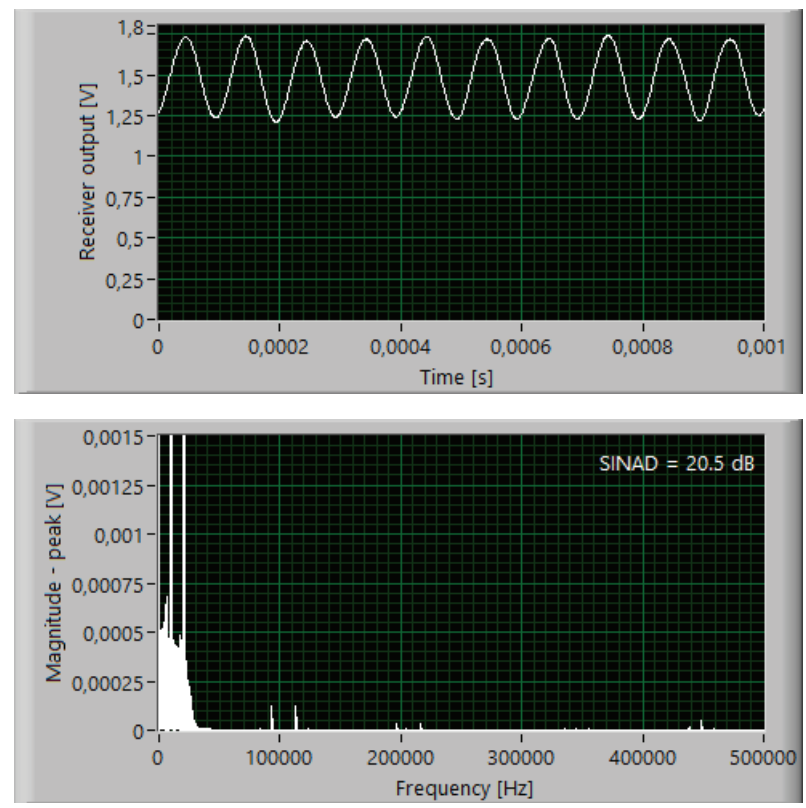

Figure 6: Measurement results for the complete receiver circuit with APD1. Top - receiver output waveform, bottom - frequency spectrum.
The complete receiver circuit with low-pass filter and the converter module $\mathrm{A} 02 \mathrm{~N}-5$ was tested after the diode comparison test. The measurement results for APD1 are shown in Figure 6. The top waveform graph displays the receiver output sinewave with frequency $10 \mathrm{kHz}$, and $500 \mathrm{mV}$ peak-to-peak value obtained from the optical sinewave signal with $90 \mathrm{pW}$ peak-to-peak instant power value, while the bottom graph displays the frequency spectrum. The low-pass filter removes high-frequency noise and the SINAD of the complete receiver circuit is $20.5 \mathrm{~dB}$.

\section{Conclusion}

The presented receiver circuit is able to amplify lowlevel fiber optical sensor signals with optical power less than $100 \mathrm{pW}$ to voltage level, which is then suitable for analog to digital conversion and further digital signal processing. The measurement results show that relatively significant differences in SINAD were obtained with apparently very similar APDs. Furthermore, to maximize SINAD for selected APD at a given target total receiver gain, an optimum setting exists between diodes' internal gain and transimpedance gain. Unfortunately, these optimum settings are usually not determinable from the typical specification parameters that are given by APD suppliers, but rather need to be determined experimentally.

With an optimally selected APD, the receiver responsivity $5.5 \mathrm{GV} / \mathrm{W}$ was obtained at avalanche multiplication $M=18$ and amplifier gain $370 \mathrm{MV} / \mathrm{A}$. Higher avalanche multiplication generates too much excess noise compared to the noise due to increased amplifier gain which is then required to get the same output voltage level. After diode selection and gain optimization, the achieved SINAD of receiver circuit with high order lowpass filter was $20.5 \mathrm{~dB}$. Further improvements of SINAD for some low-frequency fiber-optical sensor applications are possible with averaging of multiple sinewave periods, or with single tone extraction.

\section{Acknowledgements}

This work was part of the project »Ecological Safe Vehicle for green mobility - EVA4green«, which was cofinanced by the Republic of Slovenia and the European Union under the European Regional Development Fund. 


\section{References}

1. M.A. Krainak, X. Sun, G. Yang, W. Lu, Comparison of linear-mode avalanche photodiode lidar receivers for use at one-micron wavelength, in: SPIE Defense, Security, and Sensing, 2010, https://doi.org/10.1117/12.852906.

2. E. Kamrani, F. Lesage, M. Sawan, Low-Noise, HighGain Transimpedance Amplifier Integrated With SiAPD for Low-Intensity Near-Infrared Light Detection, IEEE Sens. J. 14 (1) (2014) 258-269, https://doi.org/10.1109/jsen.2013.2282624.

3. C.H.Tan, A. Velichko, L.W. Lim, J.S. Ng, Few-photon detection using InAs avalanche photodiodes, Opt Express 27 (4) (2019) 5835-5842, https://doi.org/10.1364/OE.27.005835.

4. A. Chaddad, Low-Noise Front-End Receiver Dedicated to Biomedical Devices: NIRS Acquisition System, Circuits and Systems 05 (08) (2014) 191-200, https://doi.org/10.4236/cs.2014.58021.

5. K.S. Lau, C.H. Tan, B.K. Ng, K.F. Li, R.C. Tozer, J.P.R David, G.J. Rees, Excess noise measurement in avalanche photodiodes using a transimpedance amplifier front-end, Meas. Sci. Technol. 17 (7) (2006) 1941-1946, https://doi.org/10.1088/0957-0233/17/7/036.

6. R.J. Mclntyre, Multiplication noise in uniform avalanche diodes, IEEE Trans. Electron Devices ED-13 (1) (1966) 164-168, https://doi.org/10.1109/t-ed.1966.15651.

7. P. Wright, K.B. Ozanyan, S.J. Carey, H. McCann, Design of high-performance photodiode receivers for optical tomography, IEEE Sens. J. 5 (2) (2005) 281-288, https://doi.org/10.1109/jsen.2004.841869.

8. G. Ferrari, M. Sampietro, Wide bandwidth transimpedance amplifier for extremely high sensitivity continuous measurements, Rev. Sci. Instrum. 78 (9) (2007), https://doi.org/10.1063/1.2778626.

9. L. Qiao, S.J. Dimler, A.N.A.P. Baharuddin, J.E. Green, J.P.R. David, An excess noise measurement system for weak responsivity avalanche photodiodes, Meas. Sci. Technol. 29 (6) (2018), https://doi.org/10.1088/1361-6501/aabc8b.
10. Y.-Y. Yang, S.-W. Wang, C.-Y. Hsieh, T.-C. Huang, Y.-H. Lee, K.-H. Chen, Power Management With a Low-Ripple High-Conversion-Ratio 80-V Output Voltage Boost Converter for Avalanche Photodiode System, IEEE Trans. Ind. Electron. 60 (7) (2013) 2627-2637, https://doi.org/10.1109/tie.2012.2196904.

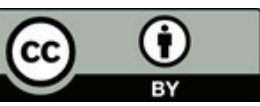

Copyright (c) 2019 by the Authors. This is an open access article distributed under the Creative Commons Attribution (CC BY) License (https://creativecommons.org/licenses/by/4.0/), which permits unrestricted use, distribution, and reproduction in any medium, provided the original work is properly cited.

Arrived: 31.07. 2019

Accepted: 13. 09. 2019 